\title{
Difference between Accounting Profit and Taxable Profit: An Analysis of Management of Accounting Results and Tax Management at Brazilian Public Companies
}

\author{
Henrique Formigoni ${ }^{\dagger}$ \\ Mackenzie Presbyterian University \\ Maria Thereza Pompa Antunes $\Omega$ \\ Mackenzie Presbyterian University \\ Edilson Paulo $\Psi$ \\ University of Paraiba
}

\begin{abstract}
This study aimed at knowing the general composition of the difference between the accounting results and tax result (book-tax differences - BTD) in Brazilian public companies in order to identify the explanation for this difference, either through the management of the earnings management (EM) and/or the taxes management (TM), or even by none of them. The research, exploratory and descriptive in nature, was based on a sample composed by the Brazilian public companies, making up a total of 276 company-years. Data analysis included the period from 2000 to 2005 and used the econometric models proposed by KS (1995) and Pae (2005) which permitted to analyze the level of management of results by means of discretionary accruals. The results achieved suggest that the models applied do not provide the support necessary for the determination of outcome management and tax management, as well as to identify the relation between these two practices and BTD. Therefore, we cannot conclude that there is a manipulation of results and/or taxes on the part of the Brazilian public companies considered in the sample, and of relation between these practices.
\end{abstract}

Keywords: results management; tax management; quality of accounting information.

Received in 06/18/2008; revised in 02/04/2009; accept in 0/24/2009.

Corresponding authors:

${ }^{\dagger}$ Professor of Mackenzie

Presbyterian University

Address: Rua da Consolação,

930, Consolação, São Paulo-

SP - Brazil - CEP: 04037-001

e-mail:

hformigoni@mackenzie.br

Telephone: (11) 2114-8292
$\Omega$ Professor of Mackenzie

Presbyterian University

Address: Rua da Consolação,

930, Consolação, São Paulo -

SP, CEP: 04037-001

e-mail:

mariathereza@mackenzie.br

Telephone: (11) 2114-8273
${ }^{\Psi}$ Adjunct Professor, Federal

University of Paraíba

Address: Avenida Esperança, no.653, Bairro Manaira - João

Pessoa-PB, CEP: 58038-281 e-mail:epaulo@ccsa.ufpb.br

Telephone: (83) 3216-7285

Editor's note: This paper was accepted by Antonio Lopo Martinez. 


\section{INTRODUCTION}

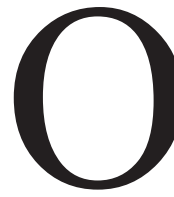

ne of the main topics of discussion in the accounting research concerns the relation between accounting and tax information (PORCANO, 1997; MILLER and SKINNER, 1998; SHEVLIN, 1999; SHACKELFORD and SHEVLIN, 2001; TANG, 2005; and ZIMMERMANN and GONCHAROV, 2005).

The tax regulation is one of the roles played by the government that affects the accounting system in that it helps in determining the amount of the tax to be collected by the firm to public treasuries (SUNDER, 1997). Thus, it appears that the accounting regulation establishes a set of accounting standards and procedures to be adopted by companies in the development and dissemination of financial information for external users, while tax legislation provides for the adoption of fiscal rules for the calculation of taxable profit.

However, the existence of different purposes between the accounting regulation and tax system creates differences between the accounting result and the taxable result (book-tax differences $-B T D$ ). The resulting value of the differences between the rules of accounting and tax reports is called, in this work, BTD.

In general lines, according to Tang (2005), the existing research on differences between the accounting system and the tax system can be divided into two tendencies. The first tendency examines the differences from the perspective of institutional arrangements, emphasizing that the differences between the accounting and tax reports are products of the discrepancy between the accounting standards and tax laws. The second tendency, in turn, focuses on incentives and opportunistic choices, arguing that these differences are influenced by the judgments of administrators who use the discretion of the accounting numbers and/or tax outcome to suit the interests of managers.

Several studies suggest the existence of strong incentives for discretionary behavior of managers on the accounting numbers, including the motivations of a tax nature (WATTS and ZIMMERMAN, 1986; FIELDS, LYZ and VINCENT, 2001; SHACKELFORD and SHEVLIN, 2001). Additionally, it is observed that there are evidences that corporate managers act in an opportunistic way on the accounting numbers to minimize the tax burden of firms (ZIMMERMANN, 2005; TANG, 2005).

Tang (2005), in turn, notes that most studies on management of accounting and tax results ignores either the non-discretionary differences resulting from the divergence between the accounting system and the tax system, or opportunistic differences resulting from the management of accounting results and/or management of taxes.

Considering that in the Brazilian context there is a strong influence of tax legislation in the accounting standards (LOPES and MARTINS, 2006), it is important to investigate the attribution of tax on the accounting numbers, in particular, on the management of accounting results.

Considering the above, this research aims at knowing in particular the composition of

the main difference between the accounting results and tax results in the Brazilian public companies in order to check the relation between earning management (EM), tax management (TM) and BTD , that is, to seek empirical evidence that the difference between the accounting result and the taxable result can be explained by earning management and/or tax management.

To meet the proposed objective, a research of the exploratory and descriptive type was developed based on a sample composed by 46 companies listed on the Stock Exchange of São

Paulo - Bovespa, comprising the period from 2000 to 2005, having used in the method of multiple regression and correlation to analyze the data. In the next section a brief review is made of accounting and taxation information, management of accounting results (earning 
management) and management of taxes (tax management) as well as taxation of profits. Then the methodological procedures adopted in the research and a description and analysis of the results are presented. At the end of the article, some considerations are made on the evidence found in this study.

\section{LITERATURE REVIEW}

\subsection{Accounting information and corporate taxation}

The accounting reports are potentially important means for the administration to communicate the performance of the company and its governance to the investors (PALEPU, HEALY and Bernard, 2004). According to LUDÍCIBUS (2004) and HENDRIKSEN and BREDA (1999), the accounting information has as main objective to be useful in the decisionmaking of the users.

In some countries, however, the accounting system aims at an additional objective to help in the determination of taxable profit. Thus, there is an interrelation between the system of financial accounting and tax accounting system, the first being the system responsible for the preparation and dissemination of accounting information for the external user and the second, used for compliance with tax requirements. According to the accounting and tax regulation of each country, the rules resulting from these two systems may be in greater or lesser degree, ambiguous, due to institutional and organizational characteristics of each environment.

In general, since it is expensive for the Government to establish a tax system separate from the accounting system, it uses the numbers reported in accounting reports to meet its needs for tax collection and tax supervision of companies. However, accounting rules allow a certain number of alternative criteria that allow the judgment of administrators for the measurement and accounting disclosure of transactions and economic events. As some of those accounting choices deviate from Treasury interests, often the tax legislation only allows the use of a smaller number of measuring criteria of the tax results.

The adoption of different financial accounting systems and tax accounting provides two sources of differences between the accounting and tax results (book-tax differences BTD): permanent and temporary differences. Permanent differences arise when certain income or expenses are recognized in accounting, but have no tax effects. Temporary differences occur when both systems, accounting and tax, recognize the same amount of revenue or expenditure, but differ as to the moment of recognition.

The BTD comes from this misalignment between the accounting and tax standards and is considered as non-discretionary different or normal BTD (NBTD), assuming it is a nonopportunistic application of the law. Moreover, the administrators have incentives to act in an opportunistic way, with regard to the accounting numbers and the taxable result, thereby resulting in discretionary differences or abnormal BTD (ABTD), being originated from the management of accounting results and/or management of taxes.

In summary, the amount of BTD has as origin the misalignment between the accounting and tax standards, the management of accounting results and the management of taxes, as shown in Figure 1. 


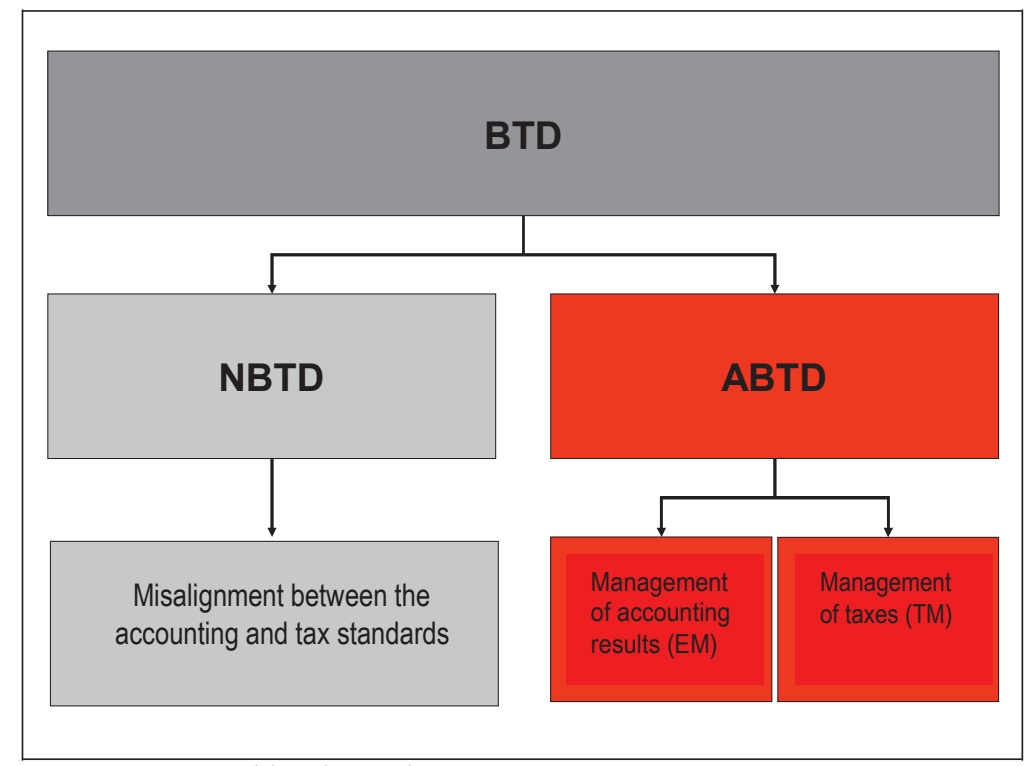

Source: Prepared by the authors

Figure 1: Composition of BTD

It is observed, however, that the detection of opportunistic behavior is made difficult, mainly by: (a) lack of an appropriate measure to measure the management of results and the management of taxes (b) the more transparent disclosure of the accounting criteria and taxes adopted and (c) the confidentiality of tax data.

With respect to the Brazilian tax system, the Regulation of Income Tax, Decree No. 3,000 of $03 / 26 / 1999$, deals with the taxation of legal entitles in Book 2 (two), providing that the income tax can be verified in three different ways: presumed profit, actual profit and arbitrated profit. There is also the possibility of the income tax being established jointly with other federal taxes through the Integrated System of Payment of Taxes and Contributions of Micro and Small Companies - SIMPLES. The income tax is the second largest collected tax in Brazil, falling behind only to the tax on operations relative to the circulation of goods and services of interstate and intermunicipal transportation and communication services - ICMS (BRAZIL, 2006).

The method of calculating income tax used by public companies (sample of this research) is based on actual profit, as required by the tax legislation. This form of taxation is part of the accounting result to verify the basis of calculation of taxable income tax, as well as the social contribution by means of additions and exclusions determined by specific tax legislation. The current Brazilian tax system also allows the compensation of previous tax losses for the calculation of income tax, and the reduction of the basis for calculation of social contribution over profits, of the negative amounts from previous years.

The taxable profit is, therefore, verified outside the established accounts, by means of the Book of Results of Real Earnings - LALUR through adjustments made on the accounting profit. If the accounting result set in LALUR results in tax loss, this may be offset by the profits of future periods up to the limit of $30 \%$ of the adjusted net income in each period. Thus, the legislation restricted the compensation of the tax loss, although it has not set a legal deadline for its use.

For purposes of calculating the income tax, the rate set by the income tax legislation is $15 \%$ and if the actual profit per annum is more than $\mathrm{R} \$ 240.000,00$ (two hundred and forty thousand reais) the income tax is subject to an additional aliquot of $10 \%$ for the profit that 
exceeds this amount. Thus, the effective aliquot, in turn, equals the percentage of profit in relation to the tax due (tax due/actual profit).

Similarly, the social contribution on net income - CSLL is due on a basis of calculation as of the accounting profit, to which additions and exclusions are made, as determined and allowed by the legislation. If the basis for calculating the CSLL is negative, it may be used to reduce the future positive basis of calculation up to the limit of $30 \%$. Therefore, the income tax and social contribution on net profit may generate a tax charge of $34 \%$ of the profit.

Tang (2005) considers that high rates of corporate tax (tax burden) imply low performance (profit) after tax and less competitive advantage, because the tax burden affect negatively the return on investment and reduce the cash flow of the companies. This fact suggests that managers seek to minimize the tax burden levied on their activities within the legal limits.

The results found by Zimmerman and Goncharov (2005) in the management of taxes by Russian companies show that the extent of management increases in accordance with the marginal tax rate. Marginal tax rate is that which focuses on each additional monetary unit of profit (BIDERMAN and ARVATE, 2004). The results of this study also show that closed companies manage taxes to a larger extent than the public companies. Accordingly, Porcano (1997), in another study, found that several characteristics of the company are associated with the management of accounting results induced by the taxation of capital gains.

\subsection{Accounting earnings management and tax management}

The management of accounting results (earnings management) is characterized as a purposeful intervention in the process of preparation of Accounting reports, caused by the judgment of the administrators on the accounting choices and/or the structuring of operational activities of the firm in order to influence the analysis of business performance by external users and, consequently, get a particular benefit (SCHIPPER, 1989; HEALY and WHALEN, 1999).

The management of accounting results and/or of taxes cannot be confused with fraud, as it is practiced within the standards prescribed by accounting standards and by tax legislation, particularly in the measurement process and disclosure that offer possibilities of decision on the part of the managers who use their discretion to report the desired result.

McNichols and Wilson (1988) affirm that the revenue and expenditures included in net profits disclosed have a discretionary and non-discretionary component, in which administrators can exercise their discretion through the selection of the accounting method and/or through the structuring of operational activities. Jones (1991) corroborates this view and states that the management of results can be achieved in several ways, such as the use of accruals, changes in accounting methods and changes in capital structure.

The accrual (accounting accumulation) is a consequence of the difference between the adoption of the competence and of the cash regimen, generating a difference between accounting net profit and net cash flow. Aharony, Lim and Loeb (1993) define total accruals of a given period as the difference between operating net profit and net cash flow of the operations. The difference in the accounting result from the adoption of the cash regimen and the competence regimen is the temporal aspect of the recognition of revenues and expenditures.

In compliance with the regimen of competence, the accounting recognition of the economic transactions and events that do not generate economic inputs or outputs of availabilities, that is, do not generate cash flows, are considered as accruals. The accruals can BBR, Braz. Bus. Rev. (Engl. ed., Online),

Vitória, Vol. 6, No. 1, Art. 3, p. 42 -58, Jan-Apr 2009

www.bbronline.com. $b r$ 
be classified into non-discretionary, which are those inherent to the activities of the company or discretionary accruals, which are those that are artificial and would only aim at manipulating the accounting result (DECHOW, SLOAN and SWEENEY, 1995; MARTINEZ, 2001).

Xiong (2006) explains that the management of the accounting results cannot be measured directly and, so, the literature provides several operational models for the detection of this practice. Accordingly, Dechow, Sloan and Sweeney (1995) argue that the analysis of the management of accounting results is usually made through the measurement of nondiscretionary accruals and discretionary accruals. The operational models to detect the management of results consider that the discretionary accruals are proxies of earnings management and that, according to Tukamoto (2004), the main models are those proposed by: Healy (1985); DeAngelo (1986), Jones (1991); modified Jones (DECHOW, SLOAN and SWEENEY, 1995), KS (KANG and SIVARAMAKRISHNAN, 1995) and Pae (2005).

The tax aspects stand out from the several incentives to manage results. The management of taxes (Tax Management - TM) corresponds to a reduction in charges for taxes on net profit (ZIMMERMANN and GONCHAROV, 2005). The management of taxes can be defined as a way for the taxpayer to explore the conditions of uncertainties and ambiguity of tax laws and apply them to advantage in the accounting measurement and in the structuring of activities with taxation favored to, legally, influence their tax burden (TANG, 2005).

In current researches (MILLS and NEWBERRY, 2001; SHACKELFORD and SHEVLIN, 2001; PLESKO, 2003; TANG, 2005), the effective tax rate (ETR), calculated by dividing the expenditure with income tax by the accounting profit before tax, is commonly used to measure TM. Although there is no consensus, Shevlin (1999) and Shackelford and Shevlin (2001) suggest that the ETR provides an appropriate measure for the effectiveness of tax management, as an opportunistic behavior results in a low ETR rate. However, this measure has information about management of taxes and tax incentives, which are the effects of discretionary tax policy, i.e. it is difficult to discover whether the reduction in the level of ETR is caused by tax exemptions or by the opportunistic behavior of the managers. This way, this proxy will introduce a measurement error in empirical results of TM.

While appropriate measures for EM and TM are controversial, according to Tang (2005), the BTD can be a good predictor of EM and part of the literature suggests that BTD may indicate TM. The intuition derived from this prediction is that the inconsistency between the financial accounting and tax accounting can be a characteristic of tax management, being that the goal is to reduce financial disbursement with taxes. The evidence described in Hanlon (2005) shows that the companies with large BTD (positive or negative) have reduced the ETR, while the empirical evidences provided by Mills (1998) suggest that a large positive BTD implies aggressive tax planning.

Motivated by the challenge in the detection of management of accounting results and tax managements and, in addition, by the deficiency existing in research on the differences between accounting profit and taxable profit (BTD), Tang (2005) used the measure of abnormal BTD to detect the management of accounting results and/or taxes of taxes in the context of Chinese public companies.

Based on Jones (1991), Tang developed an empirical model to detect the management of results and/or tax, through ABTD, controlling the effects of investments in fixed and intangible assets, changes in income and changes in the position of tax losses. The empirical study in China showed that the level of abnormal BTD is positively associated with the incentives for the management of accounting results and management of taxes. The magnitude of abnormal BTD remits to the existence and level of managerial manipulations, suggesting 
that abnormal BTD is an alternative metric for management of accounting results and management of taxes.

However, this relation between BTD and management of results is controversial. The works developed by Phillips, Pincus and Rego (2003) and Krull (2004) show that the operational models for the detection of results management may present a better specification with the use of deferred taxes (proxy for BTD). Despite these investigations, as well as Miller and Skinner (1998), Paulo, Corrar and Martins (2007) found that the inclusion of the variable representing tax approval does not improve the performance of the models for management of results in the Brazilian context.

\section{METHODOLOGICAL PROCEDURES}

\subsection{Type and method of research}

This research is characterized by the exploratory and descriptive type, as per guidance of Köche (1999), and Cervo Bervian (2002). The research is exploratory because it sought to obtain more knowledge about the manipulation of results and taxes in the scope of Brazilian public companies, and descriptive since it tried to check evidences of the relation between the difference between accounting results and the taxable profit and the management of accounting results and the management of taxes. As to the method, it is characterized as quantitative with the use of operational models through the analysis of correlation and multiple linear regression.

\subsection{Selection and composition of the sample}

The population was composed by the open capital corporations listed on the Stock Exchange of São Paulo - Bovespa. We excluded the companies whose main activity is the participation in other companies and the companies that did not provide sufficient data for this study. The final sample was composed by the total of 46 companies, making up an analysis of total of 276 company-years.

\subsection{Procedure for data collection}

The data and information necessary for the research were extracted from the databases of Economática ${ }^{1}$ between the years 2000 to 2005 and the Financial Statements disclosed by the companies.

\subsection{Development of hypotheses and definition of the models employed}

As explained before, the difference between the accounting result and the taxable result (BTD) can be explained by the misalignment between the accounting standards and the tax legislation, management of accounting results and/or management of taxes. Considering the above, the following research hypotheses were adopted:

H1: The management of the accounting results explains the difference between the accounting result and the taxable result (BTD) presented by the public companies in Brazil. 
H2: The management of taxes explains the difference between the accounting result and the taxable result (BTD) presented by public companies in Brazil.

To analyze the influence of management of accounting results and management of taxes in the composition of BTD, an analysis was performed according to the following operational model:

$$
B T D_{i t}=\alpha+\beta_{1} E M_{i t}+\beta_{2} T M_{i t}+\varepsilon_{i t}
$$

where:

$$
\begin{array}{ll}
B T D_{i t} & =\text { difference between the accounting result and the taxable result of company } i \text { in } \\
& \text { period } t ; \\
& =\text { proxy for management of accounting results calculated for company } i \text { in period } \\
& t ; \\
T M_{i t} & =\text { proxy for tax management calculated for company } i \text { in period } t ; \\
\varepsilon_{i t} & =\text { regression error. }
\end{array}
$$

To confirm hypothesis 1 of this work, it is expected that coefficient $\beta_{1}$ is positive and significantly different from zero $\left(\beta_{1}>0\right)$, because the higher the level of management of results, the higher the BTD. Similarly, it is expected that coefficient $\beta_{2}$ is positive and significantly different from zero $\left(\beta_{2}>0\right)$, because the higher the level of management of taxes, the higher the BTD, thus confirming Hypothesis 2.

Consistent with previous work, the model should control the characteristics particular of each economic sector in order to reduce the likelihood of the estimates contaminated by the sectorial effects, minimizing the influence of particular facts of the management of results and taxes that were not observed. It is worth emphasizing that if the model is well specified, the misalignment between the accounting standards and tax legislation will be captured by the term included in the regression and by the coefficients of economic sectors.

The proxies of management of accounting results used in this work were the discretionary accruals calculated by the KS model (1995) and by the Pae model Pae (2005) commented below.

Kang and Sivaramakrishnan (1995) propose a model (model KS) for measurement of the accruals in the management of the results described as follows:

$$
T A_{i t}=\phi_{0}+\phi_{1}\left(\delta_{1} R_{i t}\right)+\phi_{2}\left(\delta_{2} D_{i t}\right)+\phi_{3}\left(\delta_{3} P P E_{i t}\right)+\varepsilon_{i t}
$$

where:

$$
\begin{array}{ll}
T A_{i t} & =\text { Total accruals of company } i \text { in period } t ; \\
R_{i t} & =\text { net revenue of company } i \text { in period } t ; \\
D_{i t} & =\text { amount of costs and operating expenses of company } i \text { in period } t, \text { excluding } \\
& \text { depreciation and amortization expenses; } \\
P P E_{i t} & =\text { balance of the accounts of Fixed Assets and Deferred Assets (gross) of company } \\
& i \text { at end of period } t ; \\
\delta_{1} & =C R_{i, t-1} / R_{i, t-1} ; \\
\delta_{2} & =\left(I N V_{i, t-1}+\operatorname{DespAntec}_{i, t-1}+C P_{i, t-1}\right) / D_{i, t-1} ; \\
\delta_{3} & =\text { Depr } \\
C R_{i-t-1 t} / P P E_{i, t-1} ; & =\text { balance of accounts receivables (customers) of company } i \text { in period } t-1 ;
\end{array}
$$


$R_{i, t-1} \quad=$ net revenue of company $i$ in period $t-1$;

$I N V_{i, t-1}=$ balance of account stocks of company $i$ in period $t-1$;

DespAntec $_{i, t-1}=$ balance of anticipated expenses account of $i$ in period $t-1$;

$C P_{i, t-1}=$ balance of accounts payables in the short term of company $i$ in period $t-1$;

$\operatorname{Depr}_{i, t-1}=$ amount of depreciation and amortization expenses for company $i$ in period $t-1$;

$P P E_{i, t-1} \quad=$ balance of the accounts of fixed assets and deferred assets (gross) of the firm $i$ at end of period $t-1$;

$\varepsilon_{i t} \quad=$ regression error.

All variables are weighted by total assets at the beginning of the period.

The model proposed by Pae $(2005$, p.6) has the purpose of increasing the predictive power of the Jones and Jones modified models, through the inclusion of variables representing the operational cash flow and natural reversal of previous accruals. The general model proposed by Pae (2005) is described as follows:

$$
T A_{i t}=\alpha\left(1 / A_{t-1}\right)+\beta_{1}\left(\Delta R_{i t}\right)+\beta_{2}\left(P P E_{i t}\right)+\beta_{3}\left(F C O_{i t}\right)+\beta_{4}\left(F C O_{i t-1}\right)+\beta_{5}\left(T A_{i t-1}\right)+\varepsilon_{i t}(3)
$$

where:

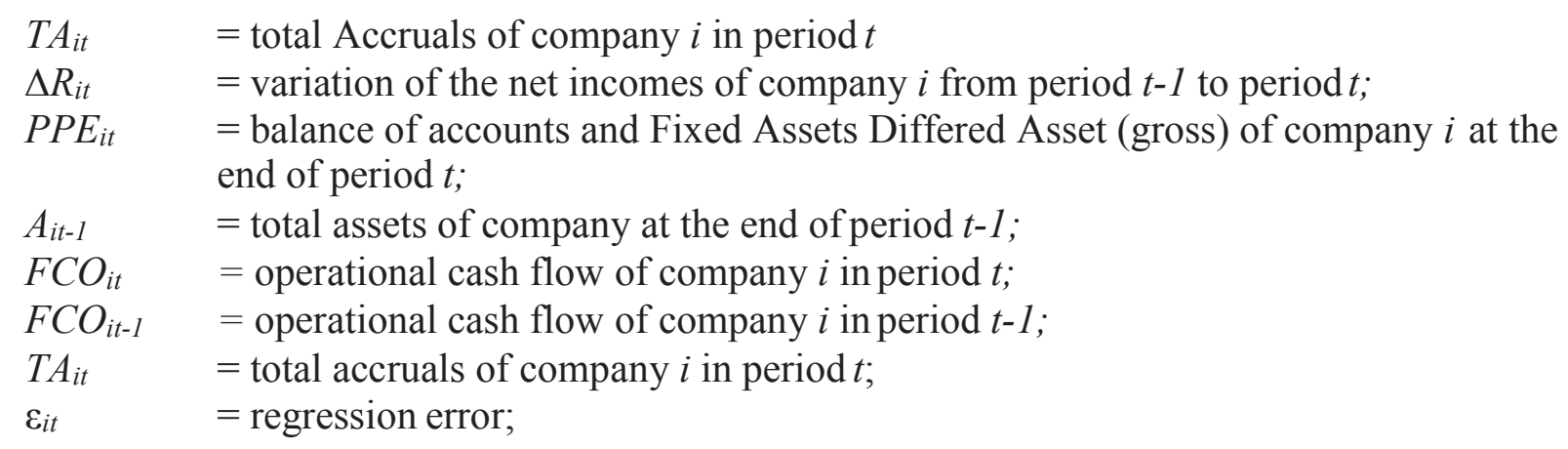

All variables are weighted by total assets at the beginning of the project.

For the two models used, the total accruals are calculated as follows:

$$
T A_{i t}=\left(\Delta A C_{i t}-\Delta D i s p_{i t}\right)-\left(\Delta P C_{i t}-\Delta D i v_{i t}\right)-D e p r_{i t}
$$

where:

$T A_{t} \quad=$ total accruals of the company in period $t$

$\triangle A C_{t} \quad=$ variation in current assets (stock) of the company at the end of period $t-1$ to the end of period $t$;

$\triangle P C_{t} \quad=$ variation of current liabilities (stock) of the company at the end of period $t-1$ to the end of period $t$;

$\Delta$ Disp $_{t}=$ variation in the availabilities of the company at the end of period t- 1 to the end of period t;

$\Delta D i v_{t}=$ variation of financing and short-term loans of the company at the end of period $t-1$ to the end of the period $t$;

Depr t $_{\text {amount }}$ of expenditures with depreciation and amortization of the company during period $t$; 
All variables are weighted by total assets at the beginning of period $t$.

Finally, the discretionary accruals of company $i$ in period $t$ are calculated as follows:

$$
D A_{i t}=T A_{i t}-N D A_{i t}
$$

where:

$D A_{t} \quad=$ discretionary accruals of the company in period $t$

$T A_{t} \quad=$ total accruals of the company in period $t$ (equation 4 );

$N D A_{t} \quad=$ non-discretionary accruals of the company in period $t$ (equation 2);

All variables are weighted by total assets at the beginning of period $t$.

The estimated value of discretionary accruals can be calculated using equation 4 or directly by the error of regression (equation 5). It is worth emphasizing that the KS model uses the method of Instrumental Variables to estimate the parameters of regression. Moreover, the proxy used to detect the management of taxes was the Effective Tax Rate (ETR), calculated by dividing the expenditure with income tax by the accounting profit before tax of company $i$ in the period.

Additionally, it was observed in the current literature that the abnormal BTD is a proxy for identification of opportunistic practices of management of accounting results and/or management of taxes (TANG, 2005). Therefore, we can establish the following hypotheses:

H3: The abnormal estimated BTD has positive correlation with the proxies of management accounting results in the context of Brazilian public companies.

H4: The abnormal estimated BTD has positive correlation with proxies for management of taxes in the context of Brazilian listed companies.

To verify the above hypotheses, we performed an analysis of correlation between the estimated abnormal BTD, in accordance with the TANG model, using the model, the discretionary accruals (calculated by the Pae and KS models) and the Effective Tax Rate (ETR).

The BTD calculated using the model proposed by Tang (2005) controls the total BTD (BTD) in relation to the effects of the investments in fixed and intangible assets, changes in income and changes in the position of tax loss, as per the following equation:

$$
B T D_{i t}=\alpha+\beta_{1} P P E_{i t}+\beta_{2} \Delta R_{i t}+\beta_{3} N O L_{i t}+\beta_{4} T L U_{i t}+\varepsilon_{i t}
$$

where:

$B T D_{i t} \quad=$ difference between the accounting result and the taxable result of company $i$ in period $t$;

$P P E_{i t} \quad=$ balance of the accounts of Fixed Assets and Deferred Assets (gross) of company $i$ at the end of period $t$, weighted by total assets at end of period $t-1$;

$\Delta R_{i t} \quad=$ variation of net revenue of company $i$ of period $t-1$ to year $t$, weighted by total assets at the end of period $t-1$;

$N O L_{i t} \quad=$ value of the negative accounting result of company $i$ of period $t$, weighted by the total assets at the end of period $t-1$; 
$T L U_{i t} \quad=$ value of the compensation for tax loss used by company $i$ of period $t$, weighted by the total assets at the end of period $t-1$;

$\varepsilon_{i t} \quad=$ regression error.

Observe that all variables are weighted by total assets to control the size of the company, while the variables and $P P E$ "6; $\mathrm{R}$ are proxies to control economic growth and $N O L$ proxy variable for tax loss. The same way that the discretionary accruals, the abnormal BTD (ABTD) is determined by the residues of equation 6 .

\section{PRESENTATION AND ANALYSIS OF RESULTS}

As previously displayed, the proxies of management of accounting results used in this work were the discretionary accruals calculated by the KS (1995) and Pae (2005) models. Thus, initially, in Table 1, the estimated parameters and statistical tests of models KS and Pae are presented, returning for the entire sample.

Table 1: Estimate of non-discretionary accruals

\begin{tabular}{l|r|r|r|r}
\hline & \multicolumn{2}{|c|}{ KS } & \multicolumn{2}{c}{ PAE } \\
\cline { 2 - 5 } & coefficient & p-value & coefficient & p-value \\
\hline $\mathrm{R}_{\mathrm{it}}$ & $-0,086016$ & 0,0000 & 0,002434 & 0,8647 \\
$\mathrm{D}_{\mathrm{it}}$ & 0,029581 & 0,5660 & & \\
$\mathrm{PPE}_{\mathrm{it}}$ & 0,227105 & 0,0119 & & \\
$\mathrm{~A}_{\mathrm{it}-1}$ & $-0,280862$ & 0,0006 & & \\
$\Delta \mathrm{R}_{\mathrm{it}}$ & & & $-4,068813$ & 0,1722 \\
$\mathrm{PPE}_{\mathrm{it}}$ & & & 0,144022 & 0,0039 \\
$\mathrm{FCO}_{\mathrm{it}}$ & & & $-0,071291$ & 0,0064 \\
$\mathrm{FCO}_{\text {it-1 }}$ & & & $-0,222615$ & 0,0216 \\
$\mathrm{TA}_{\mathrm{it}-1}$ & & & 0,096610 & 0,1722 \\
$R^{2}$ & & & 0,240852 & 0,0539 \\
$R^{2}$ adjusted & 0,089185 & & 0,193426 & \\
Akaike criterion & 0,087215 & & 0,189934 & \\
Schwarz criterion & $-0,355952$ & & $-0,402567$ & \\
Statistics F & $-0,340890$ & & $-0,376239$ & \\
& 45,27075 & 0,000 & 55,39638 & 0,000 \\
Durbin-Watson & & & & \\
White Heteroscedasticity Test & 1,543 & & 1,943 & \\
Breusch-Godfrey Serial Correlation LM Test & 73,304 & 0,000 & 866,152 & 0,000 \\
Jarque-Bera Test & 203143,300 & 0,000 & 11,854 & 0,000 \\
Notes & 27,000 & 133274,200 & 0,000 \\
& & & 276 & \\
\hline
\end{tabular}

By means of the verification of the adjusted $\mathrm{R}^{2}(\mathrm{KS}=0.087$ and Pae $=0.190)$, presented in Table 01, it is seen that the estimated models do not have a good explanatory power, although the Pae model (adjusted $\mathrm{R}^{2}=0.190$ ) has better predictive power than the KS model (adjusted $\mathrm{R}^{2}=0.087$ ).

Note, also, that the two models have a problem heteroscedasticity, self-correlation and non-normality of residues. However, based on the Central Limit Theorem, Wooldridge (2006, BBR, Braz. Bus. Rev. (Engl. ed., Online), 
p. 167) states that the estimators of the method of the Ordinary Minimum Squares (MQO) satisfies the asymptotic normality, i.e., they have approximately normal distribution in samples of sufficiently large sizes. Therefore, in spite of presenting the specific test, the assumption of normality is relaxed in the inferences about the parameters of the models because their coefficients are consistent and non-bias asymptotically even in the presence of heteroscedasticity and self-correlation.

Table 2 presents the results of the estimation of BTD according to the econometric models KS (1995) and Pae (2005).

Table 2: Estimation of the BTD

\begin{tabular}{l|r|r|r|r}
\hline & \multicolumn{2}{|c|}{ KS } & \multicolumn{2}{c}{ PAE } \\
\cline { 2 - 5 } & Coefficient & p-value & Coefficient & \multicolumn{1}{c}{ p-value } \\
\hline Constant & $-0,196088$ & 0,4720 & $-0,193291$ & 0,4941 \\
$\mathrm{EM}_{\mathrm{it}}$ & $-0,780821$ & 0,1488 & $-1,698219$ & 0,1650 \\
$\mathrm{TM}_{\mathrm{it}}$ & 0,002412 & 0,5130 & 0,002768 & 0,5021 \\
$R^{2}$ & & & & \\
$R^{2}$ adjusted & 0,000 & & 0,000 & \\
Akaike criterion & 0,000 & & 0,000 & \\
Schwarz criterion & 5,418525 & & 5,452568 & \\
Statistics F & 5,473642 & & 5,509040 & \\
& 0,156091 & 0,856 & 0,378569 & 0,685 \\
Durbin-Watson & & & & \\
White Heteroscedasticity Test & 1,233 & & 1,278 & \\
Breusch-Godfrey Serial Correlation LM & 1,383 & 0,926 & 1,782 & 0,878 \\
Test & 17,872 & 0,000 & 16,818 & 0,000 \\
Jarque-Bera Test & 23144,791 & 0,000 & 20551,154 & 0,000 \\
Notes & 271 & & 271 & \\
& & & & \\
\hline
\end{tabular}

Through the verification of the adjusted $\mathrm{R}^{2}(\mathrm{KS}=0.000$ and Pae $=0.00)$, presented in Table 2, it is observed that the models of estimation have no explanatory power. Note, also, that both models have problems of autocorrelation and non-normality of the residues, but do not have problem of heteroscedasticity. As previously reviewed (Table 1), the problems of autocorrelation and non-normality of the residues are relaxed as a result of the size of the sample (WOOLDRIDGE, 2006, p. 167).

The results displayed in Table 2 do not permit confirming Hypothesis H1 (management of accounting results explains the formation of the difference between accounting result and taxable result - BTD - presented by the Brazilian public companies), considering that the $\beta$ of TM is not significantly different than zero (p-value KS = 0.1488 and $p$-value Pae $=0.1650$ ). Thus, for the sample under study, one cannot say for sure that the difference between the accounting result and the taxable result is derived from accounting management.

The results displayed in Table 2 do not permit either to confirm Hypothesis $\mathrm{H} 2$ (management of taxes explains the formation of the difference between the accounting result and the taxable result - BTD - presented by the Brazilian public companies) considering that the $\beta$ of TM is not significantly different than zero ( $p$-value $\mathrm{KS}=0.5130$ and $\mathrm{p}$-value Pae $=$ 0.5021 ). Thus, for the sample under study, one cannot say for sure that the difference between the accounting result and the taxable result is derived from tax management. 
Table 3 shows the results of the estimate of abnormal BTD in accordance with the econometric model of Tang (2005).

Table 3: Estimate of the abnormal BTD model of Tang

\begin{tabular}{l|r|r}
\hline & \multicolumn{2}{|c}{ Tang } \\
\cline { 2 - 3 } & Coefficient & p-value \\
\hline Constant & $-0,024241$ & 0,4668 \\
$\mathrm{PPE}_{\mathrm{it}}$ & 0,065747 & 0,2287 \\
$\Delta \mathrm{R}_{\mathrm{it}}$ & $-0,233386$ & 0,0050 \\
$\mathrm{NOL}_{\mathrm{it}}$ & $-0,241996$ & 0,2414 \\
$\mathrm{TLU}_{\mathrm{it}}$ & 0,051151 & 0,7298 \\
$R^{2}$ & 0,271 & \\
$R^{2}$ adjusted & 0,243 & \\
Akaike criterion & $-0,490062$ & \\
Schwarz criterion & $-0,372021$ & \\
Statistics F & 10,42518 & 0,000 \\
& & \\
Durbin-Watson & 1,919 & \\
White Heteroscedasticity Test & 36,268 & 0,000 \\
Breusch-Godfrey Serial Correlation LM Test & 0,193 & 0,908 \\
Jarque-Bera Test & 285,312 & 0,000 \\
Notes & 271 & \\
& & \\
\hline
\end{tabular}

It's noticed through Table 3 shows that the model presents a problem of heteroscedasticity and non-normality of the residues, but has no problem of autocorrelation. In this case it also carries the same consideration made previously that the problems of heteroscedasticity and non-normality of the residues are relaxed as a result of the size of the sample (Wooldridge, 2006, p. 167).

The results of Table 3 show that the Tang's model has an explanatory power of 0.271 , but only variable $\Delta \mathrm{R}_{\mathrm{it}}$ (variation of income) is significant $(\mathrm{p}$-value $=0.005)$. The negative sign of the income variation $(-0.233386)$ indicates that when the variation of the revenue increases, the difference between the accounting profit and the taxable profit decreases. A possible explanation for this result may be in the fact that the accounting practices limit the earnings management (EM) and the tax management (TM) when the practice results in increased revenue, i.e. it is not possible to manipulate.

Table 4 shows the results of the correlation between abnormal BTD and the discretionary accruals of the KS model (1995) and discretionary accruals of the Pae model (2005).

Table 4: Correlation between ABTD and discretionary accruals of the KS and Pae models

\begin{tabular}{c|c|c|c|c}
\hline & Abnormal ABTD & $\begin{array}{c}\text { Discretionary } \\
\text { Accruals - KS }\end{array}$ & $\begin{array}{c}\text { Discretionary } \\
\text { Accruals - PAE }\end{array}$ & ETR \\
\hline Abnormal BTD & 1,000 & $-0,047$ & $-0,078$ & 0,230 \\
Discretionary Accruals - KS & $-0,047$ & 1,000 & 0,925 & 0,056 \\
Discretionary Accruals - PAE & $-0,078$ & 0,925 & 1,000 & 0,030 \\
ETR & 0,230 & 0,056 & 0,030 & 1,000 \\
\hline
\end{tabular}


The results shown in Table 4 do not permit to confirm Hypothesis H3 (estimated abnormal ABTD has positive correlation with the proxies of management of accounting results in the context of the Brazilian public companies), considering there is no correlation between the accruals, according to the two models, and the BTD. Thus, for the sample under study, one cannot affirm that the discretionary accruals, proxies for management of accounting results have correlation with the differences between accounting profit and the taxable profit BTD.

The results shown in Table 4 neither can prove the Hypothesis H4 (the estimated abnormal BTD has positive correlation with the proxies of management of taxes in the context of the Brazilian public companies), as there is no correlation between the ETR, according to the two models, and BTD. Thus, for the sample under study, one cannot say that the ETR, proxies for the management of taxes, are correlated with the differences between accounting profit and taxable profit - BTD.

\section{FINAL CONSIDERATIONS}

This study has the general objective to know the composition of the difference between the accounting results and the tax result in the Brazilian public companies so as to seek the explanation for this difference, either through earning management (MS) and/or the tax management (TM), or even, none of them. It is sustained on the fact that, according to the literature, the differences between accounting and tax issues are the result of three basic components: the misalignment between the accounting and tax standards; the management of accounting results and the management of taxes. The misalignment between the accounting and tax standards results in non-discretionary differences, while the opportunistic management of accounting and/or tax results generates discretionary differences.

It is understood that the understanding of opportunistic behavior in accounting reports is extremely important because it helps in the economic and financial analysis of companies contributing mainly to the allocation of financial resources for the establishment of contractual relations and the regulatory process of Accounting.

Therefore, in this study it was made an analysis of the relation existing between the management of accounting results and the management of taxes with BTD, using the econometric models KS (1995) and Pae (2005).

The results achieved did not accept allow accepting the hypotheses assumed, that is, one cannot say that: the difference between the accounting result and taxable result is due to accounting management (hypothesis 1), that the difference between the accounting result and the taxable result is due to tax management (Hypothesis 2); that the discretionary accruals, proxies for management of accounting results have correlation with the differences between accounting profit and taxable profit - BTD (Hypothesis 3) and that the ETR, proxies for management of taxes, have correlation with the differences between accounting profit and taxable profit - BTD (Hypothesis 4).

This does not mean, however, that there is no relation between the factors studied, but that the models so far developed for this purpose have not yet proved to be fully adequate.

Therefore, the results motivate the continuity of research that emphasize the quality of accounting information, especially in the management of taxes, given the Brazilian reality, as well as from other countries, which is characterized by a high tax burden and the effects this can result in decision-making of users of accounting information.

\section{REFERENCES}

BBR, Braz. Bus. Rev. (Engl. ed., Online),

Vitória, Vol. 6, No. 1, Art. 3, p. 42 -58, Jan - Apr 2009

www.bbronline.com. br 
AHARONY, J.; LIN, C. J.; LOEB, M.P. Initial public offerings, accounting choices, and earnings management. Contemporary Accounting Research, v. 10, n. 1, Fall 1993, p. 6181.

BALL, Ray; SHIVAKUMAR, Lakshmanan. Earnings quality UK private firms: comparative loss recognition timeliness. Journal of Accounting and Economics. v. 39. 2005. p.83-128.

BARTOV, Eli; GIVOLY, Dan; HAYN, Carla. The rewards to meeting or beating earnings expectations. Journal of Accounting and Economics. v. 33. n.2. Jun. 2002. p.173-204.

; MOHANRAM, Partha. Private information, earnings manipulations, and executive stock-options exercises. The Accounting Review. v. 79. n. 4. 2004. p.88-920.

BENEISH, Messod D. Earnings management: a perspective. Managerial Finance. v. 27. n.12. 2001. p.3-18.

BIDERMAN, Ciro; ARVATE, Paulo Roberto (Organizers). Economia do setor público no Brasil. Rio de Janeiro: Elsevier, 2004.

BRASIL. Decree 3.000. Regulamento do imposto de renda. Brasília: Congresso Nacional, 1999.

Brasília, 2006.

Secretaria da Receita Federal. Análise da arrecadação das receitas federais.

BURGSTAHLER, D.; DICHEV, I. Earnings management to avoid earnings decrease and losses. Journal of Accounting \& Economics. v. 24. n.1. Dec. 1997. p.99-126.

CERVO, Amado L.; BERVIAN, Pedro A. Metodologia científica. 5.ed. São Paulo: Prentice Hall, 2002.

DeANGELO, Linda E. Accounting numbers as market valuation substitutes: a study of management buyouts of public stockholders. The Accounting Review. v.61. n.3. Jul. 1986. p.400-420.

DECHOW, P. M.; SLOAN, R. G.; SWEENEY A. P. Detecting earnings management. The Accounting Review. v. 70, n.2, April 1995, p. 193-225.

GREENE, William H. Econometric analysis. $5^{\text {th }}$ ed. New Jersey: Prentice Hall, 2003.

HANLON, M. The persistence and pricing of earnings, accruals and cash flows when firms have large book-tax differences. Accounting Review, 80(1), p. 137-166.

HEALY, Paul M. The effect of bonus schemes of accounting decisions. Journal of Accounting and Economics. v.7. Apr. 1985. p.85-107.

; WHALEN, J. M. A review of the earnings management literature and its implications for standard setting. Accounting Horizons. Sarasota, 13, 1999, p. 365-383.

JONES, Jennifer J. Earnings management during import relief investigations. Journal of Accounting Research. Chicago, v. 29, n. 2, Autumn, 1991, p. 193-228.

KANG, S. H.; SIVARAMAKRISHNAN, K. Issues in testing earnings management: an instrumental variable approach. Journal of Accounting Research, v. 33, n. 2, Autumn, 1995, p. 353-367.

KÖCHE, José Carlos. Fundamentos da metodologia científica: teoria da ciência e prática da pesquisa. 15.ed. Petrópolis: Vozes, 1999. 
[1] LOPES, Alexandro B.; MARTINS, Eliseu. Teoria da contabilidade: uma nova abordagem. São Paulo: Atlas, 2006.

MARTINEZ, Antonio Lopo. Gerenciamento dos resultados contábeis: estudo empírico das companhias abertas brasileiras. Tese (Doutorado). São Paulo: FEA/USP, 2001.

MCNICHOLS, M.; WILSON, G. P. Evidence of earnings management from the provision for bad debts. Journal of Accounting Research, v. 26 Supplement, 1988, p. 1-31.

MILLS, L. Book-tax differences and Internal Revenue Service adjustments. Journal of Accounting Research 1998, n. 36(2), p. 343-356.

MILLER, G.; SKINNER, D. Determinants of the valuation allowance for deferred tax assets under SFAS No. 109. The Accounting Review. v. 73, n. 2, Apr. 1998. p. 105-134.

PAE, Jinhan. Expected accrual models: the impact of operating cash flows and reversals of accruals. Review of Quantitative Finance and Accounting. v. 24, n. 1, 2005. p. 5-22.

PAULO, Edilson; CORRAR, Luiz João; MARTINS, Eliseu. Detectando Gerenciamento de Resultados pela Análise do Diferimento Tributário. In: Anais XXX ENANPAD Encontro da Associação Nacional de Pós-Graduação e Pesquisa em Administração. Salvador, 2006. In CD-ROM.

PHILLIPS, John; PINCUS, Morton; REGO, Sonja O. Earnings management: new evidence based on deferred tax expense. The Accounting Review. v. 78, n. 2, Apr. 2003. p. 491-521.

PORCANO, Thomas M. An analysis of capital gains tax-induced earnings management. IAER, Nov 97, v. 3, n. 4, p. 395-408.

ROOSENBOOM, Peter; GOOT, Tjalling V. D.; MERTENS, Gerard. Earnings management and initial public offerings: evidence from the Netherlands. The International Journal of Accounting. v. 38, n.3, 2003. p. 243-266.

SCHIPPER, Katherine. Commentary on earnings management. Accounting Horizons. Dec. 1989, p. 91-102.

EMPIRICAL TAX RESEARCH IN ACCOUNTING. 2001, n. 31(1-3), p. 321-387.

SHEVLIN, T. A critique of Plesko's an evaluation of alternative measures of corporate tax rates. Working paper 1999. University of Washington.

SUNDER, Shyam. Theory of accounting and control. Cincinnati: South-Western Publishing, 1997.

TANG, Tanya Y.H. Book-Tax differences, a function of accounting-tax misalignment, earnings management and tax management - empirical evidence from China. SSRN 19/11/2005. Available at: http://papers.ssrn.com/sol3/papers.cfm?abstract_id=872389. Access in: $11 / 11 / 2006$.

TEOH, Siew Hong; WELCH, Ivo; WONG, T. J. Earnings management and the long-run market performance of initial public offerings. Journal of Finance, v. 53. n. 6. Dec. 1998. p. 1935-1974.

TUKAMOTO, Yhurika S. Contribuição ao estudo do "gerenciamento" de resultados: uma comparação entre as companhias abertas brasileiras emissoras de ADRs. Dissertação (Mestrado). São Paulo: FEA-USP, 2004. 
XIONG, Y. Earnings management and its measurement: a theoretical perspective. The Journal of American Academy of Business. Cambridge, v. 9, n. 1, March 2006, p. 214-219. WOOLDRIDGE, Jeffrey M. Introdução à econometria: uma abordagem moderna. São Paulo: Pioneira Thomson Learning, 2006.

ZENDERSKY, Humberto Carlos. Gerenciamento de resultados em instituições financeiras no Brasil - 2000 to 2004. Dissertação (Mestrado). Brasília: UnB, 2005.

ZIMMERMANN, Jochen; GONCHAROV, Igor. Earnings management when incentives compete: the role of tax accounting in Russia. 2005. Available at: $<$ http://www.ssrn.com $>$ Access on 16/06/2006.

WATTS, Ross; ZIMMERMAN, Jerold L. Positive accounting theory. New Jersey: Prentice Hall, 1986. 